\title{
RESPECTING WORKING MOTHERS WITH INFANT CHILDREN: THE NEED FOR INCREASED FEDERAL INTERVENTION TO DEVELOP, Protect, AND SUPPORT A BREASTFEEDING CULTURE IN THE UNITED STATES
}

\author{
HEATHER M. KOLINSKY* \\ INTRODUCTION
}

\begin{abstract}
A decade ago in Martinez v. NBC, Inc., ${ }^{1}$ Judge Lewis A. Kaplan remarked:
The transformation in the role of women in our culture and workplace in recent decades and the civil rights movement perhaps will be viewed as the defining social changes in American society in this century. Both have resulted in important federal, state and local legislation protecting those previously excluded from important roles from discrimination in pursuit of the goal of equality. Nevertheless, few would deny that the problems facing women who wish to bear children while pursuing challenging careers at the same time remain substantial. ${ }^{2}$
\end{abstract}

Regrettably, the intervening ten years have not brought about significant improvements for working women who would like to breastfeed their infant children. And while Judge Kaplan referred to women pursuing "challenging careers," it should be noted that any woman who wishes to breastfeed her children while continuing to work faces substantial impediments. In fact, as this article explains, for many low income women who want to breastfeed, but must work to survive, the challenges can be insurmountable.

Breastfeeding has come to a crossroads in America. The health benefits of breastfeeding are overwhelming and well-documented. ${ }^{3}$ Recently, public awareness of the tremendous advantages of breastfeeding has also risen. ${ }^{4}$

* Heather M. Kolinsky, B.A. Stetson University, J.D. Rutgers University - Camden, is an assistant professor of law at Barry University Law School in Orlando, Florida. The author thanks Richard Robbins, Jessica Van Valkenburg and Colby Ferris for their research and citation support and Patrick Tolan and Neal Hutchens for their comments and guidance.

1. 49 F. Supp. 2d 305 (S.D.N.Y. 1999).

2. Id. at 306 .

3. See Am. Acad. of Pediatrics, Policy Statement: Breastfeeding and the Use of Human Milk, 115 Pediatrics 496, 496-97 (2005) ("Human milk is species-specific, and all substitute feeding preparations differ markedly from it, making human milk uniquely superior for infant feeding.") available at http://aappolicy.aappublications.org/cgi/content/full/pediatrics;115/2/496 [hereinafter AAP Statement]. See also AGENCY FOR HEALTHCARE RESEARCH \& QUALITY, BREASTFEEDING AND MATERNAL AND INFANT HEALTH OUTCOMES IN DEVELOPED COUNTRIES (2007), available at http:/ / www.ahrq.gov/downloads/pub/evidence/pdf/brfout/brfout.pdf.

4. Lactivists have staged nurse-ins and letter writing campaigns to support a woman's right to breastfeed. Amy Harmon, "Lactivists" Taking Their Cause, and Their Babies, to the Streets, N.Y. TIMES, 
Legislation in nearly every state seeks to protect a woman's right to breastfeed her child in any public place where she has a right to be. ${ }^{5}$ Stronger notices have been proposed for infant formula to acknowledge that "breast milk is more beneficial to infants than infant formula." 6 The federal government has even implemented some limited programs to promote breastfeeding. ${ }^{7}$ Yet, even with these advances, working women still face obstacles to breastfeeding their children, ${ }^{8}$ particularly job-related impediments when they return to work. ${ }^{9}$

Federal legislation should be required to consolidate protections that have originated in the states and private corporations into a comprehensive federal policy that recognizes, values, and encourages a woman's unique ability to breastfeed. Breastfeeding women must be protected from discrimination, and comprehensive federal laws must be enacted to provide meaningful support for all breastfeeding mothers who return to the workplace. This article will address

June 7, 2005, at B3. When a women was asked to cover up or nurse in the bathroom at a Starbucks in Silver Spring, Maryland, more than 100 mothers, fathers, and infants protested at the store the following week. See Maureen Minehan, Advocates Lobby for Breastfeeding Rights in Public . . . and at Work, 21 EMP. ALERT 1 (Nov. 18, 2004).

5. As of 2009, forty-four states, the District of Columbia, and the Commonwealth of Puerto Rico protected a mother's right to breastfeed in public. See, e.g., ALASKA STAT. § 29.25.080 (2008); COLO. REV. STAT. ANN. § 25-6-302 (2008) ("A mother may breastfeed in any place she has a right to be."); N.J. STAT. ANN. § 26:4B-4 (West 2007).

6. Sen. Thomas R. Harkin introduced the HeLP America Act in 2005. S. 1074, 109th Cong. (2005). The act provides, in part, that infant formula be deemed mislabeled unless it contained the statement: "The United States Department of Health and Human Services has determined that: (1) breast-feeding is the ideal method of feeding and nurturing infants; (2) breast milk is the most complete form of nutrition for infants; and (3) breast milk is more beneficial to infants than infant formula." Id.

7. In response to the Healthy People 2010 initiative, the United States Department of Health and Human Services established the Office on Women's Health. See www.4woman.gov (last visited Mar. 31, 2010). The OWH launched the "Babies were born to be breastfed" public service campaign in 2004. Press Release, U.S. Dep't of Health \& Human Serv., Public Service Campaign to Promote Breastfeeding Awareness Launched (June 4, 2004) (available at http://www.hhs.gov/news/ press/2004pres/20040604.html). The campaign, developed in conjunction with the Ad Council, ran in print media and on television and radio. See www.4woman.gov/breastfeeding/index.cfm?page=adcouncil. The United States Breastfeeding Committee was established in 1998 and has as its mission the protection, promotion, and support of breastfeeding in the United States. See http://www.usbreastfeeding.org/AboutUs/tabid/53/ Default.aspx (last visited Mar. 31, 2010).

8. See, e.g., Derungs v. Wal-Mart Stores, Inc., 374 F.3d 428, 440 (6th Cir. 2004) (finding that department store's ban on public breastfeeding was not discriminatory under Ohio's public accommodation statute). Ohio passed a law protecting breastfeeding in public in 2005 . OHIO REV. CODE ANN. § 3781.55 (West 2006) ("A mother is entitled to breast-feed her baby in any location of a place of public accommodation wherein the mother otherwise is permitted. 'Place of public accommodation' has the same meaning as in section 4112.01 of the Revised Code.").

9. Some impediments include lack of access to appropriate facilities and break time to nurse or pump breast milk. See Shana M. Christrup, Breastfeeding in the American Workplace, 9 AM. U. J. GENDER SOC. POL'Y \& L. 471, 481 (2001) (noting that difficulties in the workplace include finding time and a convenient area to express milk). See also Alan S. Ryan \& Gilbert A. Martinez, Breast-Feeding and the Working Mother: A Profile, 83 PEDIATRICS 524, 530 (1989), available at http:// pediatrics.aappublications.org/cgi/content/abstract/83/4/524. This article will examine, in part, how little progress has been made at the federal level since Christrup reported on the state of breastfeeding in the American workplace in 2001. 
the need to recognize the rights of, and protect, breastfeeding women in the workplace. ${ }^{10}$

The next part of this article, Part I, examines the benefits of breastfeeding. In addition to the medical benefits to mother and child, financial benefits to the family and society are also explored. "Breastfeeding is a great equalizer: babies born to the poorest of the poor have the same starting point as those born to the richest of the rich. And because poorer families are less likely to have access to affordable, quality health care, this simple start in life is even more crucial."11

Part II considers the challenges facing working women in the United States and the obstacles presented by the lack of federal laws, especially for the working poor. Although ideally an infant should be exclusively breastfed for the first six months and then partially breastfed for another six months as first foods are introduced, ${ }^{12}$ few working women in the United States are able to take even six months away from work. ${ }^{13}$

A woman returning to work who is breastfeeding must either have direct access to her child in the workplace or she must pump and store her breast milk.14 Pumping and storing breast milk generally requires time to pump (usually thirty minutes at a time, twice during an eight hour period), privacy, a clean space close to her work station, and refrigeration for the pumped milk. ${ }^{15}$ These requirements have a more significant impact on lower income women, ${ }^{16}$

10. This is not a novel idea; federal legislation has been proposed time and time again for at least the last ten years. In 1998, Rep. Carolyn Maloney introduced legislation that would modify the Family and Medical Leave Act to require breaks so that mothers could pump breast milk at work. See Christrup, supra note 9, at 494-95. Rep. Maloney has offered at least three different versions of her legislation to protect breastfeeding women, including the Breastfeeding Promotion Act offered in 2003, 2005, and 2009. See H.R. 2819, 111th Cong. (2009); H.R. 2122, 109th Cong. (2005); H.R. 2790, 108th Cong. (2003). More limited legislation, aimed at protecting breastfeeding women from discrimination under Title VII, was proposed by Sen. Olympia J. Snowe in 2003. See S. 418, 108th Cong. (2003). The bill did not emerge from committee consideration. See DOUGLAS REID WEIMER, CRS REPORT FOR CONGRESS: BREASTFEEDING: FEDERAL LEGISLATION, at 5 n.29 (2005), available at http://maloney.house.gov/documents/olddocs/breastfeeding/20050505_CRS_Federal\%20Legislati on.pdf.

11. Melissa Clark Vickers, World Health Day, April 7, 2008: Protecting Health From CLIMATE CHANGE, 2 (2008), available at www.1lli.org/docs/World_Health_Day_2008_4_2_0811.pdf.

12. See AAP Statement, supra note 3, at 499. See infra Part I for a broader discussion of the benefits of breastfeeding.

13. Federal legislation, specifically the Family Medical Leave Act, provides for twelve weeks of unpaid leave under certain conditions. See 29 U.S.C. $\$ 2612$ (2006). Beyond that most women are at the mercy of state and private employers' leave policies.

14. See U.S. BREASTFEEDING COMMITTEE, WORKPLACE BREASTFEEDING SUPPORT 2 (2002), available at http://www.usbreastfeeding.org/LinkClick.aspx?link=Publications\%2fWorkplace-2002USBC.pdf.

15. U.S. BREASTFEEDING COMMITTEE, WORKPLACE ACCOMMODATIONS CHECKLIST (2003) available at http://www.usbreastfeeding.org/LinkClick.aspx?link=Publications\%2fWorkplace-Checklist2002-USBC.pdf.

16. SusAn Egerter et Al., The Henry J. KAISER Found., DisParities in MATERnAl \& Infant Health: ARe We MaKing Progress? Lessons From CALIFORnia 13-14 (2004) (finding that disparities existed based upon race/ethnicity, education and income). The study concluded that educational attainment of both a woman and her partner was a stronger predictor of breastfeeding. See JUdiTH LAUWERS \& ANNA SWISHER, COUNSELING THE NURSING MOTHER: A LACTATION CONSUltANT'S GUIDE 487 (Jones \& Bartlett Publishers) (4th ed. 2005) (citing Sharon G. Hills-Bonczyk 
because these women frequently must return to work soon after having a baby and they often have jobs that are not conducive to continuing breastfeeding. ${ }^{17}$ For example, a woman who works in a retail store or on an assembly line may have limited access to a private place to pump breast milk and often has little control over when she may take a break to express breast milk. ${ }^{18}$ In contrast, for women who have an office with a door and have control over how they spend their workday, breastfeeding may only require minimal accommodation. ${ }^{19}$ Part III details how current legislation and workplace demographics have created this two-class system for support of breastfeeding. ${ }^{20}$

The United States, while not the only country to face this problem, has failed to support breastfeeding policies that would benefit all working women when compared to the rest of the world. ${ }^{21}$ At best, the United States has made an effort to acknowledge the problem and address it with education, ${ }^{22}$ but it has also reinforced socio-economic disparities where there should be none, in the treatment of working women who care for our youngest and most vulnerable citizens. Finally, Part II examines specific legal protections afforded to breastfeeding women in the United States under current federal and state laws and their shortcomings.

In Part III, the author proposes comprehensive federal legislation that would support a breastfeeding woman in the workplace regardless of education, socio-economic status, or place of employment.

In spite of the efforts of a handful of legislators, the move toward federal protection for a breastfeeding woman's rights in the workplace and supporting her ability to breastfeed or pump breast milk in the workplace has remained stagnant. $^{23}$ Given the well-documented physical, emotional, and monetary benefits of exclusively breastfeeding an infant for the first six months of life, ${ }^{24}$ it is hard to understand the reasons why such legislation continues to fail.

et al., Women's Experiences with Combining Breastfeeding and Employment, 38 J. NURSE-MIDWIFERY, 257 (1993).

17. See Hills-Bonczyk et al., supra note 16 , at 257 .

18. Christrup, supra note 9 , at 481 .

19. Id.

20. See, e.g., Jodi Kantor, On the Job, Nursing Mothers Find a 2-Class System, N.Y. TIMES, Sept. 1, 2006 at A1 (examining breastfeeding policies at Starbucks where a woman in the corporate office was treated to a special room and equipment while another employee, who worked in a retail outlet, chose to abandon breastfeeding for lack of a place to pump).

${ }^{21}$ For example, working mothers in the European Union are entitled to a minimum of fourteen weeks paid maternity leave. See Council Directive 92/85/EEC, art. 8, 1992 O.J. (L 348) 1 (EC) (the introduction of measures to encourage improvements in the safety and health at work of pregnant workers and workers who have recently given birth or are breastfeeding). In October 2008, a proposal was made to raise the paid maternity leave minimum from fourteen weeks to eighteen weeks for member states. Press Release, European Commission, Longer and Better Maternity Leave for Millions (Oct. 3, 2008) (available at http://ec.europa.eu/social/main.jsp?langId=enEcatId= 89EnewsId=402).

22. See supra note 7 (citing education campaigns launched by the United States Breastfeeding Committee and the United States Department of Health and Human Service through OWH).

23. See supra note 10.

24. AAP Statement, supra note 3, at 496-97. See infra, Part II, subsection B. 


\section{THE AdVANTAGES OF BREASTFEEDING.}

Breastfeeding provides "diverse and compelling" health, nutritional, immunologic, developmental, psychological, social, economic, and environmental benefits. ${ }^{25}$ The first section discusses the distinct physiological benefits that accrue to both mother and child from breastfeeding; the second section addresses the diverse ancillary benefits.

\section{A. Physiological Benefits}

Breastfeeding is a process that is uniquely female. ${ }^{26}$ An increase in hormones when a woman gives birth causes milk to develop in ducts located in the breast. ${ }^{27}$ Breast milk "comes in" approximately two days after a woman gives birth. ${ }^{28}$ The production of breast milk can continue as long as a child feeds from the breast or a woman pumps her breast milk. ${ }^{29}$

Breast milk is primarily composed of water, proteins, carbohydrates, and lipids. ${ }^{30}$ The composition of breast milk changes daily, even during feedings, to accommodate a nursing infant's needs. ${ }^{31}$ It contains critical immune system protection that passes to the child from the mother. ${ }^{32}$ Breast milk is the ultimate in designer food, specially tailored for the child who will receive it. ${ }^{33}$

Breastfed infants are less likely to contract a wide range of infectious diseases, including bacterial meningitis, diarrhea, respiratory tract infections, ear infections, and urinary tract infections than non-breastfed infants. ${ }^{34}$ Even when breastfed infants contract these infectious diseases, the severity and length of the

25. AAP Statement, supra note 3, at 496-97.

26. Wallace v. Pyro Mining Co., 789 F. Supp. 867, 869 (W.D. Ky. 1990).

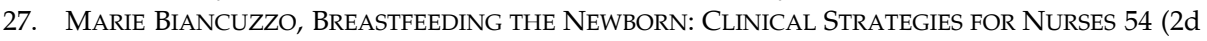
ed. 2003) (noting that oxytocin and prolactin are primarily responsible for milk production).

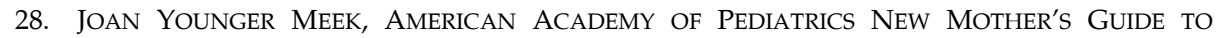
BREASTFEEDING 23 (Sherill Tippins ed., 2002). While a woman's milk production begins before she gives birth, in the form of colostrum, transitional breast milk does not develop until a few days later. Id. Finally, mature milk arrives near the end of the second week after childbirth. Id. at 24-26.

29. BIANCUZZO, supra note 27 , at 65.

30. Id. at 65-66. Breast milk also contains water-soluble vitamins, ionic constituents, trace minerals and cells. Id. Human milk contains over 200 known components. LAUWERS \& SWISHER, supra note 16 , at 163 .

31. BIANCUZZO, supra note 27 , at $67,69-71$. For example, fat content is higher in colostrum than in mature milk. Id. The content of fat in breast milk changes during the day, peaking in the afternoon and evening. Id. at 67. Even during a feeding, fat content varies between foremilk and hindmilk. Id. See also LAUWERS \& SWISHER, supra note 16, at 159.

32. BIANCUZZO, supra note 27 , at 71 .

33. Id. at 72. See LAUWERS \& SWISHER, supra note 16, at 165 ("The mother gives her child the specific protection he needs for the environment in which they live, both in terms of allergens and infection protection."). While breastfeeding is ideal, not everyone can breastfeed. AAP Statement, supra note 3 , at 497 . In particular, women with HIV are advised not to breastfeed, and often a woman cannot breastfeed if she is taking certain medications. Id.

34. AAP Statement, supra note 3 , at 496 . Breast milk contains many anti-bacterial and "antiinfective" properties and acts as a conduit for the passage of immunologic agents that protect an infant from many different microorganisms. LAUWERS \& SWISHER, supra note 16, at 166-69 (Tables 9.2, 9.3, and 9.4). 
disease is reduced.35 Studies have also concluded that breastfeeding results in decreased rates of sudden infant death syndrome in the first year of life. ${ }^{36}$

Breastfeeding's benefits follow a child through her later life as well. Breastfed children are far less likely to develop Type I and II diabetes, high cholesterol, and asthma. ${ }^{37}$ Evidence also indicates children who are exclusively breastfed for at least six months suffer from fewer allergies. ${ }^{38}$ More recent research suggests that breastfed children have a lower risk of becoming obese in childhood and later life. ${ }^{39}$ The significance of the lower incidence and severity of these diseases cannot be understated. Studies have also demonstrated that breastfed infants score higher on intelligence tests than their formula-fed counterparts. ${ }^{40}$

Mothers also benefit from breastfeeding. Mothers experience less postpartum bleeding and side effects such as anemia. ${ }^{41}$ These same mothers lose weight more quickly after giving birth. ${ }^{42}$ Over the long term, mothers who choose to breastfeed may have lower blood sugar, higher HDL cholesterol, and a lower incidence of breast, ovarian, and uterine cancers. 43

\section{B. Other Benefits of Breastfeeding.}

\section{Financial}

The protection breastfeeding provides to infants from dangerous infections and potentially life-threatening illnesses results in significant savings to both health insurance companies and employers. ${ }^{44}$ "For private and government

35. AAP Statement, supra note 3 , at 496.

36. Id.

37. Id. at 496-97.

38. LAUWERS \& SWISHER, supra note 16, at 171 (citing J. Van Odijk et al., Breastfeeding and Allergic Disease: A Multi-disciplinary Review of the Literature (1966-2001) on the Mode of Early Feeding in Infancy and Its Impact on Later Atopic Manifestations. 58 ALLERGY 833 (2003); Syed Mohammed Tariq et al., The Prevalence of and Risk Factors for Atopy in Early Childhood: A Whole Population Birth Cohort Study, 101 J. ALLERGY \& CLINICAL IMMUNOLOGY 587 (1998).).

39. U.S. BREASTFEEDING COMMITTEE, STATEMENT ON THE IMPORTANCE OF BREASTFEEDING/Human MilK FEEDING IN THE PREVENTION OF OBESITY (2003), available at http:// www.usbreastfeeding.org/LinkClick.aspx?link=Position-Statements\%2FObesity-Statement-2003USBC.pdf (citing Kathryn G. Dewey, Is Breastfeeding Protective Against Child Obesity?, 19 J. HuM. LACTATION 9 (2003); Matthew W. Gillman et al. Breast-feeding and Obesity, 141 J. PEDIATRICS 749, 74950 (2002) (Studies indicate that increased duration in breastfeeding predicted lowered risk for obesity in later years.)).

40. AAP Statement, supra note 3, at 497.

41. Alicia Dermer, A Well-Kept Secret: Breastfeeding's Benefits to Mothers, 18 NEW BEGINNINGS 124 (2001), available at http://www.lalecheleague.org/NB/NBJulAug01p124.html (citing RUTH A. LAWRENCE \& ROBERT M. LAWRENCE, BREASTFEEDING: A GUIDE FOR THE MEDICAL PROFESSION (5th ed. 1999).).

42. Id.

43. Id.

44. U.S. BREASTFEEDING COMMITTEE, ECONOMIC BENEFITS OF BREASTFEEDING (2002), available at http:/ / www.usbreastfeeding.org/LinkClick.aspx?link=Publications\%2FEconomic-Benefits-2002USBC.pdf. See also Tara Swenson, Insuring A Healthier Society: The Need for Breastfeeding Promotion and Support Through Private Insurance and Government Initiatives, 16 KAN. J.L. \& PUB. POL'Y 20 (2006). 
insurers, a minimum of $\$ 3.6$ billion must be paid each year to treat diseases and conditions which can be prevented or diminished by breastfeeding." 45

In addition to the health care savings for parents, employers, and insurers, breastfeeding results in a direct financial benefit to the family. If a mother chooses to breastfeed her infant, then she may incur the expense of a lactation consultation, nursing pads, and some related items. If she returns to the workplace, then she will generally require a breast pump and storage bottles, but those are generally her only expenses. ${ }^{46}$ This is far less expensive than the $\$ 1,500$ a family can expect to spend to provide an infant with formula for the first year of life. ${ }^{47}$ The expense of choosing formula over breast milk not only impacts individual families, it also impacts federal programs. Nearly \$578 million per year is spent by the Special Supplemental Nutrition Program for Women, Infants and Children ("WIC") to provide formula to participants and their children. ${ }^{48}$ In comparison, a breastfeeding mother on WIC costs the program forty-five percent less than a mother who gives her baby formula. ${ }^{49}$

\section{Environmental Benefits.}

Breastfeeding is an environmentally sound practice. ${ }^{50}$ It causes less agricultural pollution than infant formula because it does not rely on cow's milk or soy (the primary ingredients of infant formula). ${ }^{51}$ Additionally, breast milk does not create the same landfill waste that is created by the manufacture and use of formula.52 Breast milk does not need to be manufactured and delivered, nor does a mother need to travel any distance to purchase it or expend any energy to heat water to mix with it, although it may need to be heated if it has been pumped or stored. ${ }^{53}$

Not only does breastfeeding protect the environment, but this closed-circuit system can also protect infants from environmental hazards. Breastfed children are not unnecessarily exposed to potential toxins such as bisphenol-A, that may be carried in cans of formula or plastic baby bottles, as well as environmental contaminants that may be found in bottled or tap water used to mix powdered

45. U.S. BREASTFEEDING COMMITTEE, supra note 44 (citing Jon Weimer, The Economic Benefits of Breastfeeding: A Review and Analysis. 13 U.S. DEP'T OF AGRIC. FOOD ASSISTANCE \& NUTRITION RES. REP. (2001), available at http:/ / www.ers.usda.gov/publications/fanrr13/fanrr13.pdf).

46. Elizabeth M. Ward, Breastfeeding Moms Going Back to Work, FAMILY EDUCATION, http:// life.familyeducation.com/breastfeeding/working-parents/39371.html; BABY CENTER, Choosing a Breast Pump, http://www.babycenter.com/0_choosing-a-breast-pump_429.bc; Mayo Clinic Staff, INFANT AND TODDLER HEALTH, Breast-feeding: Choosing a Breast Pump, http:/ /www.mayoclinic.com/ health/breast-feeding/PR00002.

47. See U.S. BREASTFEEDING COMMITTEE, supra note 44.

48. Id.

49. Id.

50. Kim Diana Connolly, The Ecology of Breastfeeding, 13 SOUTHEASTERN ENVTL. L.J. 157 (2005).

51. Id. at 161-62. Soy contributes to water and land pollution based on clear cutting and the use of fertilizers to grow the crop.

52. Id. at 162-63.

53. Id. at 162 . 
infant formula. ${ }^{54}$ Infants are also protected from misuse and improper mixing of formula which can affect the balance of nutrients. ${ }^{55}$

The introduction of melamine into milk used for infant formula in China exemplifies one danger inherent in relying so heavily on fabricated baby formulas. ${ }^{56}$ Over 50,000 infants were sickened by melamine in infant formula, approximately 13,000 babies were hospitalized, and at least three deaths were linked to tainted infant formula. ${ }^{57}$

The United States is not immune to this type of problem. There have been over forty-seven formula or infant food recalls in the past twenty-two years in the United States. ${ }^{58}$ Recently, traces of melamine and cyanuric acid have been detected in domestically produced infant formula. ${ }^{59}$ This discovery begs the question as to what other industrial or environmental contaminants may be present in infant formula. The discovery of melamine and cyanuric acid in domestic infant formula also highlights the reason why it is important for all women to have a viable choice to continue breastfeeding when they return to work. 60

54. Bisphenol A ("BPA") is a chemical that is used to make polycarbonate plastic bottles and to line canned and powdered. It is also widely used to make plastic baby bottles. THE WORK GROUP FOR SAFE MARKETS, BABY'S TOXIC BOTTLE: BISPHENOL A LEACHING FROM POPULAR BABY BOTTLES 6 , available at http://www.chej.org/documents/BabysToxicBottleFinal.pdf. See also QEA: Baby Bottles and Bisphenol A, CONSUMER REP., Mar. 27, 2008, http://blogs.consumerreports.org/baby/2008/03/ qa-baby-bottles.html. The chemical is "a developmental, neural, and reproductive toxicant that mimics estrogen and can interfere with healthy growth and body function." THE WORK GROUP FOR SAFE MARKETS, supra, at 4. Canada recently announced a ban on most plastic baby bottles. Ian Austen, Canada Takes Steps to Ban Most Plastic Baby Bottles, N.Y. TIMES, Apr. 19, 2008, at C2. While pumped breast milk would also require a bottle to feed an infant, the breast pump kits and collection and storage materials available from Medela, one of the most recognized brands of breast pumps, are BPA-Free. See Medela, http://www.medelabreastfeedingus.com/products/breastmilkcollection (last visited Apr. 3, 2010).

55. LAUWERS \& SWISHER, supra note 16, at 173. Approximately 1.5 million deaths occur each year worldwide from incorrect or inadequate use of infant formula. Id. The danger is increased in poorer communities with substandard conditions and low education levels. Id. (citing MARSHA WALKER, SELling OUT MOTHERS AND BABIES: MARKETING OF BREAST MILK SUBSTITUTES IN THE USA (2001)).

56. See Jim Yardley, 13,000 Babies in Hospital for China Formula, N.Y. TIMES, Sept. 21, 2008, at A13.

57. FOOD \& DRUG ADMIN., INTERIM SAFETY AND RISK ASSESSMENT OF MELAMINE AND ITS ANALOGUES IN FOOD FOR HUMANS (2008), http://www.fda.gov/Food/FoodSafety/ FoodContaminantsAdulteration/ChemicalContaminants/Melamine/ucm164522.htm.

58. LAUWERS \& SWISHER, supra note 16, at 175 (citing reports available at www.fda.org). The recalls were required because of incorrect preparation or packaging or bacterial contamination.

59. Andrew Martin, Melamine Traces Found in U.S. Infant Formula, N.Y. TIMES, Nov. 26, 2008, at A19. The levels of melamine and a related chemical, cyanuric acid, found in the formula were extremely low. Id.

60. On October 3, 2008, the Food and Drug Administration issued a statement that it was "currently unable to establish any level of melamine and melamine-related compounds in infant formula that does not raise public health concerns." See Joan Lowy and Justin Pritchard, How Much Melamine in Babies' Formula is Risky? FDA Sets Level, ORLANDO SENTINEL, Nov. 29, 2008, at A15. On November 28, 2008, the FDA changed its position, based upon further study, and set a safety threshold for industrial melamine in formula at 1 part per million for melamine as long as cyanuric acid is not present as well. Id. See FOOD \& DRUG ADMIN., UPDATE: INTERIM SAFETY AND RISK ASSESSMENT OF MELAMINE AND ITS ANALOGUES IN FOOD FOR HUMANS (2008), http:/ /www.fda.gov / Food/FoodSafety/FoodContaminantsAdulteration/ChemicalContaminants/Melamine/ucm164520. 


\section{Ancillary Workplace Benefits.}

In addition to the reduced costs of health insurance benefits, employers receive other benefits from a minimal investment in breastfeeding support. ${ }^{61}$ An employer that supports a woman's decision to continue breastfeeding and allows her to pump breast milk at work upon her return may experience a reduction in parental absenteeism. ${ }^{62}$ Generally, when an infant becomes ill, a parent must keep the baby out of child care until the infant recovers. Unless a parent has a private babysitter, the mother will be unable to work until her child is well. Since breastfed children suffer from fewer and less severe illnesses, the parent is not forced to use sick leave or unpaid leave to care for the child. In addition, over time employers have experienced greater loyalty from mothers who are supported in their efforts to continue breastfeeding. ${ }^{63}$ This loyalty results from the employer's support of a breastfeeding mother at a time of transition when she is returning to work. ${ }^{64}$ The employer's support helps facilitate a return to work and does not force a mother to choose between breastfeeding her child or supporting her family. ${ }^{65}$

\section{BREASTFEEDING MOTHERS IN THE UNITED STATES}

\section{A. The Current Climate in the United States.}

Consider a woman who works the counter at a fast food restaurant. If she is able to take any leave when she gives birth, it is more likely to be unpaid and abbreviated. ${ }^{66}$ Since she will be forced to return to work more quickly, her abbreviated leave may prompt her to forgo breastfeeding altogether. Even if she initiates breastfeeding, when she returns to work the nature of her job or her workspace may be such that pumping breast milk is simply not an option. ${ }^{67}$

htm; FoOd \& Drug Admin., Melamine CONTAMination In China (2009), http://www.fda.gov/ NewsEvents/PublicHealthFocus/ucm179005.htm; Bloomberg News, F.D.A. Allows Trace Amounts of Chemical in Formula, N.Y. TIMES, Nov. 29, 2008, at B2. The Illinois Attorney General has demanded a national recall of the affected infant formulas based upon the FDA's earlier statement that no level of melamine was safe. See Martha Mendoza \& Justin Pritchard, Calls for National Infant Formula Recall Spread, AsSOCIATED PRESS FIN. WIRE, Nov. 26, 2008.

61. See U.S. BREASTFEEDING COMM., supra note 44.

62. AAP Statement, supra note 3, at 497 (less disease results in decreased parental employee absenteeism).

63. Id. See U.S. DeP'T OF HeAlth \& Human Servs., The Business Case FOR BreastFeeding: STEPS FOR CREATING A BREASTFEEDING FRIENDLY WORKSITE, available at http:// www.womenshealth.gov/breastfeeding/programs/business-case/outreach-marketing-guide.pdf

64. Press Release, Medela, Survey: Corporate Lactation Programs Increase Retention (Sept. 25, 2007) (available at www.medelabreastfeedingus.com/media-center/17/survey-corporate-lactationprograms-increase-retention) (noting that ninety-six percent of the 100 best companies in the Working Mother survey provide dedicated lactation rooms to a majority of their workforce).

65. Id.

66. Generally, women who work full time, who have at least a bachelor's degree, or who are older are more likely to receive paid maternity leave. See TALLESE D. JOHNSON, U.S. CENSUS BUREAU, CURRENT POPUlATION REPORTS: MATERNITY LEAVE AND EMPLOYMENT PATTERNS OF FiRST-TiME MOTHERS: 1961-2003 (2008), available at http:/ / www.census.gov/prod/2008pubs/p70-113.pdf.

67. Kantor, supra note 20; Christrup, supra note 9 at 480-81. See also Tara Parker-Pope, Most Moms Give Up on Breast-Feeding, N.Y. TIMES, Aug. 11, 2008, http://well.blogs.nytimes.com/ 2008/08/11/ most-moms-give-up-on-breast-feeding (returning to work decreases the likelihood of 
Even a woman in an administrative support position may suffer in the same way. If a woman does not have flexibility in her schedule and a place to pump, then the desire to breastfeed is often squelched by the demands and realities of the workplace. ${ }^{6}$

This is not an inconsequential problem. Statistics compiled by the U.S. Census Bureau show the percentage of women who return to work after childbirth is sizeable. In the years 2000, 2002, and 2004, some fifty-five percent of women who gave birth reentered the workforce within one year. ${ }^{69}$ With the workplace so heavily populated with working mothers and the benefits of breastfeeding long-recognized, the limited recognition of the importance of supporting a woman's ability to pump breast milk at work is unfortunate. In fact, the United States pledged to take progressive action to support breastfeeding initiatives nearly twenty years ago.

1. A Commitment to Support Breastfeeding.

In 1990, the United States was a party to the Innocenti Declaration on the Protection, Promotion and Support of Breastfeeding, a World Health Organization and United Nations Children's Fund joint policy statement. ${ }^{70}$ One of the charges of the Declaration required governments to enact "imaginative legislation protecting the breastfeeding rights of working women and established means for its enforcement."71

continued breastfeeding). In order to pump breast milk at work, a woman would need two twentyminute breaks during an eight-hour day, a private place to pump her milk, a sink to wash her pump equipment and her hands, and refrigeration to keep the milk fresh until she went home.

68. This may explain why breastfeeding's initiation rate in 2003 and 2004 was nearly seventyfive percent but the rate of children who were breastfed for at least six months was only about thirtysix percent, and the rate of children who were breastfed exclusively for six months was only about fifteen percent. Renata Forste \& John P. Hoffmann, Are US Mothers Meeting the Healthy People 2010 Breastfeeding Targets for Initiation, Duration, and Exclusivity? The 2003 and 2004 National Immunization Surveys, 24 J. HUM. LACTATION 278, 281 (2008).

69. Jane LaWler Dye, U.S. Census Bureau, CurRent POPUlation RePORTS: Fertility OF AMERICAN WOMEN: JUNE 20047 (2005), available at http://www.census.gov/prod/2005pubs/p20555.pdf. The United States Department of Health and Human Services, in its Blueprint for Action on Breastfeeding, noted that among employed mothers with children under the age of three, one-third returned to the work force within three months of giving birth and two-thirds returned within six months. U.S. DEP'T OF HEALTH \& HUM. SERVS., OFFICE OF WOMEN'S HEALTH, BREASTFEEDING: HHS BLUEPRINT FOR ACTION ON BREASTFEEDING 16 (2000) available at http://www.womenshealth.gov/ archive/breastfeeding/programs/blueprints/bluprntbk2.pdf. [hereinafter HHS BLUEPRINT]. African American mothers are more likely to return to work earlier and are more likely to engage in jobs that do not allow successful continuation of breastfeeding. Id.

70. World Health Org. [WHO] \& U.N. Children's Fund [UNICEF], Breastfeeding in the 1990s: A Global Initiative, Florence, Italy, July 30-Aug. 1, 1990, Innocenti Declaration, available at http://www.unicef.org/programme/breastfeeding/innocenti.htm. The Declaration was the result of a meeting, "Breastfeeding in the 1990s: A Global Initiative," sponsored by the U.S. Agency for International Development and the Swedish International Development Authority; BIANCUZZO, supra note 27, at 10 . The United States has also signed the Convention on the Rights of the Child, a human rights resolution prepared by the United Nations General Assembly in 1989, that went into force in 1990, but it has failed to ratify the treaty. See Convention on the Rights of the Child, Nov. 20, 1989, 28 I.L.M. 1456, 1577 U.N.T.S. 3.

71. WHO \& UNICEF, supra note 70. The Declaration lists four main goals for the participating governments. 
In 1992, Congress enacted the Breastfeeding Promotion Program as a part of the Child Nutrition Programs administered by the Secretary of Agriculture. ${ }^{72}$ The Breastfeeding Promotion Program sought to promote breastfeeding, and to assist in the distribution of pumping equipment to breastfeeding women. ${ }^{73}$

In 1993, Congress passed the Family and Medical Leave Act ("FMLA"). ${ }^{74}$ The FMLA provided, among other things, that a woman was entitled to up to twelve weeks of unpaid leave from her job to care for her newborn child. ${ }^{75}$ The Act does not apply to all employers, ${ }^{76}$ and it does not always provide twelve weeks postpartum leave if the mother is required to leave her job before the birth of her child for medical reasons. ${ }^{77}$ In an indirect manner, the FMLA provided the first real legal protection to women who wanted to establish breastfeeding before returning to work. ${ }^{78}$ It was enacted in response to women's movement into the workforce and the recognition of employees' needs to balance family and job responsibilities. ${ }^{79}$

Even though the United States was educating women about the benefits of breastfeeding and providing some preliminary protection to women who wanted to breastfeed, by 1998, only sixty-four percent of women tried breastfeeding, only twenty-nine percent continued at six months, and only sixteen percent continued to breastfeed for one full year. ${ }^{80}$

In 1998, the Department of Health and Human Services established the United States Breastfeeding Committee. ${ }^{81}$ The Committee's mission is to "improve the nation's health by working collaboratively to protect, promote,

72. 42 U.S.C. $\$ 1790$ (2006); see WEIMER, supra note 10, at 4.

73. WEIMER, supra note 10 , at 3 .

74. 29 U.S.C. § 2601 (2006). Interestingly, the FMLA was not the first family leave law in the United States. As with breastfeeding access and support, states led the way and filled the void until the FMLA was passed. Donna Lenhoff \& Claudia Withers, Implementation of the Family and Medical Leave Act: Toward the Family-Friendly Workplace, 3 AM. U. J. GENDER \& L. 39, 42 (citing Donna R. Lenhoff \& Sylvia M. Becker, Family and Medical Leave Legislation in the States: Toward a Comprehensive Approach, 26 HARV. J. ON LEGIS. 403, 442-45 (1989)).

75. 29 U.S.C. § 2612(a)(1) (2006). See also 29 U.S.C. § 2611(2) (2006) (In order to be eligible for FMLA leave to care for a newborn child, an employee must have been employed by the same employer for twelve months or for at least 1250 hours.).

76. 29 U.S.C. § 2611(4)(A)(i) (2006). An employer is defined as "any person engaged in commerce or in any industry or activity affecting commerce who employs 50 or more employees for each working day during each of 20 or more calendar workweeks in the current or preceding calendar year."

77. See 29 U.S.C. § 2612(a)(1)(A), (D)(2006).

78. Studies indicate that, as of 1998, the FMLA provided maternity leave for approximately half of American working women but that its impact was limited. Kristen E. Smith \& Amara Bachu, Women's Labor Force Attachment Patterns and Maternity Leave: A Review of the Literature Table 8, (U.S. Census Bureau, Population Division Working Paper No. 32, 1999), available at http:// www.census.gov/population/www/documentation/twps0032/twps0032.html.

79. Lenhoff \& Withers, supra note 74 , at 48.

80. U.S. DeP'T OF HeAlth AND HuM. Servs., Focus Area 16: Maternal, Infant, and Child Health, in HEALTHY PEOPLE 2010: UNDERSTANDING AND IMPROVING HEALTH,16-46 (2d ed. 2000), available at http://www.healthypeople.gov/Document/pdf/Volume2/16MICH.pdf [hereinafter HEALTHY PEOPLE 2010];

HHS BLUEPRINT, supra note 69 , at 9.

81. See Welcome to the United States Breastfeeding Committee, http:// www.usbreastfeeding.org (last visited Apr. 3, 2010). 
and support breastfeeding." 82 Around the same time, the federal government set breastfeeding rate goals as part of the Healthy People 2010 program ("Healthy People 2010").83 Healthy People 2010 sought to eliminate health disparities between different socioeconomic groups, and it identified breastfeeding as one of its focus areas. ${ }^{84}$ This program has become the benchmark by which the federal government determines this country's progress in breastfeeding rates. In fact, the legislation underlying the Breastfeeding Promotion Program now directs that "there is to be cooperation between the federal government and 'communities, State and local agencies, employers, health care professionals, and other entities in the private sector to build a supportive breastfeeding environment for women participating in the program under this section to support the breastfeeding goals of the Healthy People 2010 initiative.'" 85

The targets for 2010 were set at seventy-five percent for initiation of breastfeeding, fifty percent at six months, and twenty-five percent at one year. ${ }^{86}$ In 2005, the HHS adjusted the objectives of Healthy People 2010 to reflect a measure and goal for exclusive breastfeeding at three and six months in addition to the other goals listed..$^{87}$

In 2000, the United States Department of Health and Human Services created a "Blueprint for Breastfeeding." 88 The Blueprint was designed to serve as a guide for building support for breastfeeding in the United States. ${ }^{89}$ It specifically recognized the need to create workplace environments that enabled mothers to continue breastfeeding as long as they desire..$^{90}$

82. See U.S. Breastfeeding Committee: About Us, http://www.usbreastfeeding.org/ AboutUs/tabid/53/Default.aspx (last visited Apr. 3, 2010).

83. HeAlthy PEOPLE 2010, supra note 80.

84. Healthy People 2010: What Are Its Goals?, http://www.healthypeople.gov/About/ goals.htm (last visited Apr. 3, 2010). See HeAlthy PEOPLE 2010, supra note 80, at 16-46. Healthy People seeks to increase the proportion of mothers who breastfeed their babies. Id. The text notes that the "lowest rates of breastfeeding are found among those whose infants are at highest risk of poor health and development: those aged 21 years and under and those with low educational levels." Id. Goals for breastfeeding rates were first set in Healthy People 2000, but those goals were not met. HHS BLUEPRINT, supra note 69 , at 8.

85. WEIMER, supra note 10, at 3-4 (citing Child Nutrition and WIC Reauthorization Act of 2004, Pub. L. No. 108-265 § 203(e)(2)(c), 118 Stat. 729 (2004)); 42 U.S.C. § 1786(h)(4)(F)(2006).

86. HEALTHY PEOPLE 2010, supra note 80, at 16-46; HHS BLUEPRINT, supra note 69, at 9.

87. Breastfeeding Trends and Updated National Health Objectives for Exclusive Breastfeeding-United States, Birth Years 2000-2004, MMWR WKLY., Aug. 3, 2007, available at http://www.cdc.gov/ mmwr/preview/mmwrhtml/mm5630a2.htm (citing U.S. DEP'T OF HEALTH AND HUM. SERVS., HEALTHY PEOPLE 2010 MIDCOURSE REVIEW, available at http://www.healthypeople.gov/ data/midcourse). In 2007, the objectives for exclusive breastfeeding were set at sixty percent through three months and twenty-five percent through six months. $I d$. This shift signaled recognition within the HHS that exclusive breastfeeding through six months was the gold standard in public health policy.

88. HHS BLUEPRINT, supra note 69.

89. Id.

90. Id. at 16 . 
2. Progress by the Numbers.

In 2004, the initiation rate for breastfeeding was 73.8 percent; the nonexclusive breastfeeding rate at six months was at 36.4 percent; and the nonexclusive rate for breastfeeding at one year was 17.7 percent nationally. ${ }^{91}$ The rate of exclusive breastfeeding through six months, however, was only 11.3 percent. $^{92}$ Not surprisingly, the rate of exclusive breastfeeding through six months for women with an income-to-poverty ratio of less than 100 percent was 8.3 percent, while the rate for more affluent women (with an income-to-poverty ratio of more than 350 percent) was fourteen percent. ${ }^{93}$ Women who were black, young, single, received a high school education or less, lived in rural areas, or were poor had the lowest rates of exclusive breastfeeding, even at the threemonth mark. ${ }^{94}$

By 2005 only eight states had achieved all three original Healthy People 2010 objectives: Alaska, California, Hawaii, Idaho, Oregon, Utah, Vermont, and Washington. ${ }^{95}$ This was not a mere coincidence. At least three of these states have enacted comprehensive legislation requiring or encouraging employers to accommodate a woman who wishes to continue breastfeeding when she returns to work. ${ }^{96}$ Some of the lowest rates of breastfeeding initiation and maintenance are found in the South, including Louisiana, Mississippi, Alabama, and Kentucky. ${ }^{97}$ Each of these states has no legislation that directs employers to support expressing breast milk in the workplace and only one, Mississippi, directs that employers may not prohibit the expression of breast milk during an employee's regular break periods. ${ }^{98}$ Other states performed better with respect to initiating breastfeeding, but have had difficulty achieving the Healthy People

91. Id.; CTRS. FOR DiseAse CONTROL \& PREVEnTION, BREASTFEEDING AMONG U.S. ChILDREN BORN 1999-2006: CDC NATIONAL IMMUNIZATION SURVEY (2008), available at http:// www.cdc.gov/breastfeeding/data/NIS_data/index.htm

92. Id. However, in reviewing similar survey results, some researchers have arrived at different rates. See Forste \& Hoffmann, supra note 68, at 282, Table 2. In their analysis, Forste and Hoffmann report a 15.5 percent rate of exclusive breastfeeding through six months with a swing from 14.1 percent to seventeen percent based upon income-to-poverty ratios. These rates are still well below the desired twenty-five percent rate set forth by Healthy People 2010.

93. Forste \& Hoffmann, supra note 68, at 282, Table 2.

94. Press Release, Centers for Disease Control \& Prevention, More Women Choosing to Breastfeed, but Rates of Exclusive Breastfeeding Fall Short of National Objectives (Aug. 2, 2007), available at http://www.cdc.gov/media/pressrel/2007/r070802.htm?s_cid=mediarel_r070802 (citing Breastfeeding Trends and Updated National Health Objectives for Exclusive Breastfeeding-United States, Birth Years 2000-2004, MMWR WKLY., Aug. 3, 2007, available at http://www.cdc.gov/ mmwr/preview/mmwrhtml/mm5630a2.htm).

95. CTRS. FOR DiseAse CONTROL \& PREVENTION, supra note 91; CTRS. FOR DiSEASE CONTROL \& PREVENTION, BREASTFEEDING REPORT CARD, UNITED STATES: OUTCOME INDICATORS, (2009), available at http://www.cdc.gov/breastfeeding/data/report_card2.htm [hereinafter CDC Report Card]. Ten states achieved the goals for exclusive breastfeeding through three months, and eight states achieved the goals for exclusive breastfeeding through six months. Id.

96. HaW. ReV. Stat. ANN. § 378-2(7) (LexisNexis Supp. 2009); CAL. LaB. CODE § 1030 (West 2003); OR. REV. STAT. $§ 653.077$ (2009). The state recently changed its statute to require employers to accommodate breastfeeding women at work. OR. REV. STAT. § 653.077 (2009).

97. See CDC Report Card, supra note 95; MISS. CODE. ANN. § 71-1-55 (Supp. 2009).

98. Miss. CODE. ANN. § 71-1-55 (Supp. 2009). 
2010 exclusive breastfeeding objectives. $^{99}$ As the data may suggest, comprehensive federal legislation is critical to enable these breastfeeding objectives to be met. The most recent statistics from the National Immunization Survey indicate that breastfeeding rates have continued to improve. ${ }^{100}$ Despite these promising gains, a review of recent data confirms that, consistent with previous research, non-hispanic blacks, less educated women, and socioeconomically disadvantaged groups still have lower breastfeeding rates. ${ }^{101}$ Breastfeeding rates continue to be highest among married women, older women, and women with higher levels of education and income.102 Breastfeeding rates remain lowest among young, black, poor mothers with less education. ${ }^{103}$ In order to increase breastfeeding rates among all socio-economic groups, working women should receive accommodations essential to continuing to breastfeed once they have returned to work.

B. The Legal Landscape in the United States with Respect to Federal Law.

Currently, no federal statute protects a breastfeeding woman from discrimination in the workplace based on her breastfeeding status, and no federal statute requires an employer to accommodate a woman who chooses to continue breastfeeding upon her return to work. ${ }^{104}$

Title VII of the Civil Rights Act of 1964 protects a woman from discrimination in the workplace based on her sex. ${ }^{105}$ In 1978, Congress passed the Pregnancy Discrimination Act which codified the Equal Employment Opportunity Commission's position that an employer could not discriminate against a woman regarding pregnancy, childbirth, or related medical conditions. ${ }^{106}$

The Pregnancy Discrimination Act was enacted with the express purpose of overturning the United States Supreme Court ruling in General Electric Company

99. CDC Report Card, supra note 95. Those states include Arizona, Arkansas, Texas, Oklahoma, Tennessee, North Carolina, West Virginia, Pennsylvania, New York, New Hampshire, New Jersey, District of Columbia, and Delaware.

100. See sources cited supra note 87. CTRS. FOR DiseASE CONTROL \& PREVENTION, NATIONAL IMMUNIZATION SURVEY supra note 91.

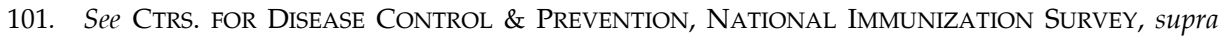
note 95 (Key Findings of NIS Survey); Forste \& Hoffmann, supra note 68, at 278.

102. Forste \& Hoffmann, supra note 68 , at 278.

103. Id. at 278-79.

104. As noted previously, only the FMLA offers a woman any sort of accommodation before she returns to work, but even the FMLA does not provide protection when a woman returns to work. See Family and Medical Leave Act, 29 U.S.C. § 2601 (2006).

105. 42 U.S.C. § 2000(e) (2006). Under Title VII it is an unlawful employment practice to discriminate against a person in the workplace based upon race, color, religion, gender or national origin with respect to compensation, terms, conditions or privileges of employment.

106. See Pregnancy Discrimination Act of 1978, Pub. L. No. 95-555, 92 Stat. 2076 (codified as amended at 42 U.S.C. $\$ 2000 \mathrm{e}(\mathrm{k})(2006)$ ). The pertinent language provides that "the terms 'because of sex' or 'on the basis of sex' include, but are not limited to, because of or on the basis of pregnancy, childbirth, or related medical conditions; and women affected by pregnancy, childbirth, or related medical conditions shall be treated the same for all employment-related purposes ...." Id. 
v. Gilbert. ${ }^{107}$ In Gilbert, female employees filed suit against their employer claiming sex discrimination based on the exclusion of pregnancy-related disabilities from the employer's disability plan. ${ }^{108}$ The Supreme Court held that the exclusion of pregnancy from the disability policy did not constitute discrimination under Title VII because it was not a gender-based exclusion and there was no indication that the denial of disability benefits was anything other than a decision not to cover a specific physical condition. ${ }^{109}$ The Supreme Court reached this conclusion even though the EEOC had interpreted Title VII to protect pregnancy-related disabilities from discrimination. ${ }^{110}$ While the Pregnancy Discrimination Act clarified that pregnancy, childbirth, and related medical conditions were entitled to protection under Title VII, several federal courts have found that breastfeeding is not included within the protection provided to women for "pregnancy, childbirth, and related medical conditions."111 These courts have recognized, however, that breastfeeding is a "uniquely female attribute" like pregnancy. ${ }^{112}$ These cases can be divided into two groups, those decided before the enactment of the FMLA, and those decided after.

\section{Pre-FMLA Cases.}

With respect to the pre-FMLA cases, the courts addressed an employer's decision whether to grant or extend disability or medical leave to women so that they could breastfeed. ${ }^{113}$ In Wallace v. Pyro Mining Co., an employee claimed that her employer discriminated against her on the basis of her sex when it failed to extend her disability leave so that she could continue to breastfeed her infant

107. 429 U.S. 125, 145-46 (1976); H.R. REP. NO. 95-948 (1978), at 2, 3 reprinted in 1978 U.S.C.C.A.N. 4749, 4750-51; Newport News Shipbuilding \& Dry Dock Co. v. E.E.O.C., 462 U.S. 669, 670 (1983) (noting that Congress decided to overrule the decision in Gilbert by amending Title VII to prohibit sex discrimination on the basis of pregnancy).

108. Gilbert, 429 U.S. at 127.

109. Id. at 139-40. In his dissent, Justice Brennan noted that the Court's reasoning relied primarily on the logic of Geduldig v. Aiello, 417 U.S. 484, 496-97 (1974), that "[t]here is no risk from which men are protected and women are not. Likewise, there is no risk from which women are protected and men are not." Id. at 147-48. Instead, the Court focused on a lack of identity between the excluded disability and gender because there were only two potential recipients: pregnant women and non-pregnant persons. Id. at 135. Because women were part of each group of potential recipients, there could be no gender discrimination absent some pretext or other evidence to the contrary.

110. The 1972 EEOC guideline provided, "Disabilities caused or contributed to by pregnancy, miscarriage, abortion, childbirth, and recovery therefrom are, for all job-related purposes, temporary disabilities and should be treated as such . . . . [Benefits] shall be applied to disability due to pregnancy or childbirth on the same terms and conditions as they are applied to other temporary disabilities." 29 C.F.R. § 1604.10(b)(1975), as cited in Gilbert, 429 U.S. at 140-41. In coming to its conclusion, the Supreme Court noted that the EEOC's interpretation was promulgated some eight years after the law was enacted and that the guideline contradicted an earlier interpretation that was provided closer to the time of Title VII's enactment. Gilbert, 429 U.S. at 141-42.

111. Wallace v. Pyro Mining Co., 789 F. Supp. 867, 869 (W.D. Ky. 1990). See Barrash v. Bowen 846 F.2d 927, 931 (4th. Cir. 1988).

112. Wallace, 789 F. Supp. at 869.

113. Id.; McNill v. N.Y. City Dep't of Corr., 950 F. Supp. 564, 568 (S.D.N.Y. 1996). 
because the infant would not accept a bottle.114 The district court first analyzed the employee's claim under the standard announced in Gilbert and found that the employer's decision to deny personal leave for breastfeeding did not deny anyone personal leave on the basis of sex, it merely excluded one situation from that leave policy. ${ }^{115}$ The district court then reviewed the employee's claim under the Pregnancy Discrimination Act and found that while "breastfeeding and weaning are natural concomitants of pregnancy and childbirth, they are not 'medical conditions' related thereto."116 The court specifically found that "related medical conditions" was intended to address disabilities that arose from pregnancy such as abortion, miscarriage, childbirth, and recovery related thereto. ${ }^{117}$ Essentially, the district court viewed the employee's claim as one based on the desire to care for her child, not a medical reason related to her pregnancy and childbirth. The result was that a woman who gave birth and chose to breastfeed her infant was afforded less protection under the Pregnancy Discrimination Act than a woman who had miscarried or who chose to have an abortion would receive.

In McNill v. New York City Department of Correction, a woman claimed that legitimate, pregnancy-related absences from June through November 1991 were improperly excluded from her pregnancy and maternity leave resulting in adverse employment actions at work. ${ }^{118}$ McNill claimed that her absence was pregnancy-related, and therefore protected under Title VII, because she had to breastfeed her son during that time due to his birth defects. ${ }^{119}$

The district court found that an infant's medical condition did not fall with the definition of "pregnancy, childbirth, or related medical condition" and thus did not come within the purview of Title VII. ${ }^{120}$ It also found that the PDA was designed to protect a mother's disability due to pregnancy or childbirth and not to protect the care of a child, which would not be a "medically determined condition related to pregnancy." 121

\section{Post-FMLA cases.}

While there have been reported cases related to breastfeeding since the enactment of the FMLA in 1993, the nature of the claims raised by breastfeeding

114. Wallace, 789 F. Supp. at 868. The employee contended that "[h]er six-week-old infant refused a bottle and 'tenaciously insisted on breast-feeding, to the exclusion of all other food.'" Id.

115. Id. at 868-69.

116. Id. at 869 .

117. Id.

118. 950 F. Supp. 564, 568 (S.D.N.Y. 1996).

119. Id. at 566. The employee's obstetrician released her to return to work in June 1991, but her medical leave was extended due to emotional problems and the need to breastfeed her son who was born with a cleft palate and cleft lip. Id.

120. Id. at 569-70 ("I cannot conclude that malfunction of the infant's palate and lip can be considered a 'condition related to pregnancy or childbirth.' Conditions related to pregnancy or childbirth would directly involve the condition of the mother.").

121. Id. at 570 (quoting H.R. REP. NO. 95-948 (1978), at 4, 5 reprinted in 1978 U.S.C.C.A.N. 4749, 4753). 
mothers have changed.122 Some cases have addressed extending an administrative leave beyond the leave an employer has already provided; others have addressed women who sued based upon their belief that they were discriminated against or fired because of their desire to breastfeed, and at least one case directly addressed accommodations in the workplace. ${ }^{123}$ The following is an examination of some of the cases decided in any category since the enactment of the FMLA.

In Martinez v. NBC, Inc., the Southern District Court of New York determined that a breastfeeding woman could not maintain a claim under the Americans with Disabilities Act. ${ }^{124}$ The underlying claim, as identified by the court, was that MSNBC "was insufficiently accommodating of plaintiff's desire to pump breast milk in the workplace so that she could breast feed her child [after] returning to work promptly after childbirth."125

In 1997, Martinez returned to work after taking maternity leave. ${ }^{126}$ Martinez chose to continue breastfeeding her son when she returned to work. ${ }^{127}$ Her employer permitted her to pump breast milk three times a day for periods of about twenty minutes in an empty edit room. ${ }^{128}$ Martinez became uncomfortable when she was pumping because other employees attempted to enter the edit room on occasion. In addition, she complained of a less favorable work schedule that interfered with child care. ${ }^{129}$ Martinez also complained that male co-workers made offensive comments about her breastfeeding on three occasions. ${ }^{130}$

The court considered whether Martinez's status as a breastfeeding woman rendered her a "qualified individual with disability" under the Americans with

122. See Puente v. Ridge, 324 F. App'x 423, 424-25 (5th Cir. 2009) (employee sued after employer failed to adequately accommodate her request to pump breast milk at work by allowing her additional paid break time, employee sued under Title VII); Vachon v. R.M. Davis, Inc., 2004 U.S. Dist. LEXIS 6339 at *39 (D. Me. Apr. 13, 2004) (employee included failure to accommodate breastfeeding as part of a disparate treatment claim under Title VII and the PDA); Fortier v. U.S. Steel Group, 2002 U.S. Dist. LEXIS 11788 at ${ }^{* 6}$ (W.D. Pa. June 4, 2002) (employee claimed discrimination and disparate treatment based, in part, on fact she expressed her intention to breastfeed after giving birth); Gallegos v. Dep't. of Interior, 6 F. App'x 865, 866 (Fed. Cir. 2001) (employee who was denied an extended leave to breastfeed her child and failed to return to work for an additional three and a half months, claimed retaliation when she was fired); Martinez, 49 F. Supp. $2 \mathrm{~d}$ at 308 (employee claimed discrimination based on failure to adequately accommodate need to pump upon return to work). Under the FMLA, employers with more than fifty employees within a certain geographic area are required, under certain circumstances, to give a woman up to twelve unpaid weeks of leave to care for her infant after childbirth. 29 U.S.C. § 2612 (2006). See 29 U.S.C. § 2611(4)(A)(i) (2006).

123. See, e.g., Martinez, 49 F. Supp. $2 \mathrm{~d}$ at 305.

124. Id. at 309 .

125. Id. at 306 .

126. Id. at 306-07.

127. Id. at 307.

128. Id.

129. Id. The court specifically noted that Martinez's scheduling issues were related to child care, not her ability to pump at work.

130. Id. 
Disabilities Act (ADA), and found that it did not. ${ }^{131}$ The court next considered whether Martinez could maintain a sex-plus discrimination claim against her employer under Title VII. ${ }^{132}$ "Sex-plus" discrimination occurs when a person is subject to disparate treatment based on her sex-plus a second characteristic. ${ }^{133}$

To prevail on her sex-plus discrimination claim, Martinez first had to prove that there was a corresponding subclass of members of the opposite sex. ${ }^{134}$ The court found that Martinez could not advance a sex-plus discrimination claim where there was no corresponding sub-class of members of the opposite sex.135

Simply put, the court found that there can be no claim of sex-plus discrimination based upon disparate treatment of a breastfeeding woman because there is no corresponding sub-class of breastfeeding men. ${ }^{136}$ The Supreme Court has found, however, that treating a woman with young children differently from a man with young children can be the basis for a proper claim of sex-plus discrimination. ${ }^{137}$ Thus, a breastfeeding mother's status as a parent does not prevent her from maintaining a sex-plus discrimination claim under Title VII-it is only her ability to lactate that does so.

A few courts have expanded the application of sex-plus discrimination to comparators within the same protected class who lack the "plus" characteristic. ${ }^{138}$ Under this interpretation, a breastfeeding woman could claim sex-plus discrimination where she was treated differently from women who were not breastfeeding. ${ }^{139}$ This view is not the popular one, and it abandons a

131. Id. at 308. The court noted that every court to consider this question had ruled that "'pregnancy and related medical conditions do not, absent unusual conditions, constitute a [disability] under the ADA.'" Id. (quoting Lacoparra v. Pergament Health Ctrs., Inc., 982 F. Supp. 213, 228 (1997)). At least one author has argued that the court in Martinez misapplied the definition of "disability" and that lactation should be accommodated under the ADA. See Hilary Von Rohr, Access to Justice: The Social Responsibility of Lawyers: Recent Development: Lactation Litigation and the ADA Solution: A Response to Martinez v. NBC, 4 WASH. U. J.L. \& POL'Y 341 (2000).

132. Martinez, 49 F. Supp. $2 \mathrm{~d}$ at 310.

133. Id. "It is impermissible to treat men characterized by some additional characteristic more or less favorably than women with the same added characteristic." Id. (citing Fisher v. Vassar Coll., 70 F.3d 1420, 1448 (2d Cir. 1995)). This type of claim was first recognized by the United States Supreme Court in Philips v. Martin Marietta Corp., 400 U.S. 542, 543-44 (1971).

134. See Derungs v. Wal-Mart Stores, Inc., 374 F.3d 428, 439 (6th Cir. 2004) ("Gender-plus plaintiffs can never be successful if there is no corresponding subclass of members of the opposite gender." This is because such plaintiffs cannot make the requisite showing that they were treated differently from similarly situated members of the opposite sex.); Fisher, 70 F.3d at 1448 (Court agreed that the only way to maintain sex-plus claim was to predicate it upon the tenure experiences of women who took extended leaves of absence from their work for any reason with men who also took long leaves of absence.).

135. Martinez, 49 F. Supp. 2d at 310-11 (quoting Coleman v. B-G Maint. Mgmt. of Colo., Inc., 108 F.3d 1199, 1203 (10th Cir. 1997)).

136. Id.

137. Philips, 400 U.S. at 543-44.

138. See Philipsen v. Univ. of Mich. Bd. of Regents, 2007 U.S. Dist. LEXIS 25898, at *22 (E.D. Mich. Mar. 22, 2007) (citing Gee-Thomas v. Cingular Wireless, 324 F. Supp. 2d 875, 884 n.6 (M.D. Tenn. 2004)).

139. Id. at *23-24. See, e.g., McGrehaghan v. St. Denis Sch., 979 F. Supp. 323, 327 (E.D. Pa. 1997) (sex-plus discrimination claim survived summary judgment when mother with disabled child was replaced by woman without disabled child); Philipsen, 2007 U.S. Dist. LEXIS at *23 (holding that "the 
core concept of gender discrimination that "to be actionable... gender-plus discrimination must be premised on gender."140

Kristen Fortier alleged that she was subject to harassment after she advised her employer she was pregnant and she intended to breastfeed. ${ }^{141}$ She claimed that her employer warned it might interfere with her job performance. ${ }^{142}$ Approximately five weeks later, she was called into a meeting and asked to resign; she refused.143 Her claim came before the Western District Court of Pennsylvania on a motion to dismiss. ${ }^{144}$ The court characterized her complaint as one of gender discrimination, sexual harassment, and disparate treatment under Title VII. ${ }^{145}$

Fortier was required to present a short and plain statement of her claim showing she was entitled to relief in order to survive a motion to dismiss. ${ }^{146}$ The district court found that Fortier stated a cause of action for pregnancy discrimination and/or sexual harassment that could survive a motion to dismiss, but that her claim regarding her intent to breastfeed failed because she was only a potential member of the class of women who intended to breastfeed. ${ }^{147}$

In short, legal decisions on all levels have found that breastfeeding resides in a parallel universe. It is not a federally recognized disability, but like a disability it requires accommodation in the workplace when a woman returns to work. It is "uniquely female," just as pregnancy is, but discrimination based on it does not rise to the level of actionable workplace discrimination because it is not a medical condition related to pregnancy. This gap in federal protection means that there is no protection for women from harsh, inconsiderate work environments and, as such, a woman's ability to continue breastfeeding upon her return to work can be limited.

The underlying logic offered by some early court decisions was that a woman chooses to breastfeed and formula is an acceptable substitute, just as

point of Philips and its progeny is that a defendant should not be able to escape liability for discrimination on the basis of sex merely by hiring some members of the protected group").

140. Philipsen, 2007 U.S. Dist. LEXIS at 25 (quoting Coleman, 108 F.3d at 1203). Indeed, it appears in some cases that gender discrimination claims were being avoided by hiring from within the protected class. In those cases, "piercing the gender veil" may be necessary to remedy a discriminatory action clothed as a nondiscriminatory action.

141. Fortier v. U.S. Steel Group, 2002 U.S. Dist. LEXIS 11788, at *1-2 (W.D. Pa. June 4, 2002).

142. Id. at $* 2$.

143. Fortier claimed she had received no negative criticism of her work before that meeting. Id. at*3. She was accused of misfiling an important microfiche. Id.

144. Id. at *1.

145. Id. at *5-6. Fortier's complaint was somewhat unclear, but the court construed her claims as emanating from protections found under Title VII, more specifically the Pregnancy Discrimination Act. Id.

146. Id. at *8-9 (citing Swierkiewicz v. Sorema, N.A., 534 U.S. 506, 512 (2002)); Fed. R. Civ. P. $8(\mathrm{a})(2))$.

147. Id. at ${ }^{*} 10-11$. The district court did not address the question of whether such women were protected by Title VII or the Pregnancy Discrimination Act. Instead, the court found that the harassment Fortier suffered was based on her status as a pregnant woman. Id. 
child care is an acceptable substitute for a mother who chooses to work. ${ }^{148}$ No man can breastfeed, and in our society no other female caretaker can breastfeed, yet courts-by choice or by legal constraint-are unwilling to incorporate breastfeeding protection into the existing legal framework. ${ }^{149}$

The legal rationale that breastfeeding is a child care choice is simply wrong. There is no adequate substitute for the nourishment afforded by mother's milk because it is ideally suited to her infant. In this society, only a mother can meet this important need, and it should be a need she has the right to satisfy. Although this "breastfeeding=childcare" logic has been abandoned somewhat by more recent court decisions, the legal constraints remain. ${ }^{150}$ There is no available method to protect a woman from discrimination, disparate treatment, or harassment in the workplace if she chooses to breastfeed.

While the federal government and the courts have faltered in providing support for breastfeeding women, some states have been more aggressive in addressing the need. ${ }^{151}$ An array of approaches exist, with some states affording minimal protections, some allowing voluntary protection, and some imposing complete protection for breastfeeding women. ${ }^{152}$ The next section explores the approaches of the most successful states as a model for improving protection at the federal level.

\section{The States' Solutions.}

Forty-four states protect a woman's right to breastfeed in public, although Missouri only allows a woman to do so "with as much discretion as possible" and, in Tennessee, the protection only extends to children who are twelve months or less. ${ }^{153}$ Twenty-eight states specifically exempt women who breastfeed in public from public indecency laws and criminal statutes. ${ }^{154}$ Unfortunately, the majority of states neither protect nor encourage breastfeeding or expressing breast milk in the workplace. ${ }^{155}$ Only twenty-four states provide any statutory protection for women in the workplace who wish to express breast milk. ${ }^{156}$ This hit and miss legal protection afforded to breastfeeding women is

148. See, e.g., Wallace v. Pyro Mining Co., 789 F. Supp. 867, 869-70 (W.D. Ky. 1990) (court found that "child-care concerns" such as being able to stay home with a child or breastfeeding a child are not covered by Title VII or the Pregnancy Discrimination Act).

149. Martinez, 49 F. Supp. 2d at, 309.

150. See id.

151. See infra Part II, subsection C.

152. Id.

153. See Mo. Rev. StAT. § 191.918 (West 2004); TenN. CODE ANN. § 68-58-101 (2006).

154. Those states include Alaska, Arizona, Arkansas, Florida, Illinois, Kentucky, Louisiana, Massachusetts, Michigan, Minnesota, Mississippi, Montana, Nevada, New Hampshire, New York, North Carolina, North Dakota, Oklahoma, Pennsylvania, Rhode Island, South Carolina, South Dakota, Tennessee, Utah, Virginia, Washington, Wisconsin, and Wyoming. See NAT'L CONFERENCE OF STATE LEGIS., BREASTFEEDING STATE LAWS, http://www.ncsl.org/default.aspx?tabid=14389 (last visited Apr. 27, 2010).

155. Alabama, Alaska, Arizona, Delaware, Florida, Idaho, Iowa, Kansas, Kentucky, Louisiana, Maryland, Massachusetts, Michigan, Missouri, Nebraska, Nevada, New Hampshire, New Jersey, North Carolina, Ohio, Pennsylvania, South Carolina, South Dakota, Utah, and Wisconsin. See id.

156. The following states have some law related to breastfeeding in the workplace: Arkansas, California, Colorado, Connecticut, Georgia, Hawaii, Illinois, Indiana, Maine, Minnesota, Mississippi, 
typical of the patchwork of state legislation that has been produced in the last twenty years. It is the reason why federal legislation has become so critical, so that all women can have the same workplace opportunities with respect to breastfeeding. What follows is an examination of the good, the bad, and the ugly with respect to state statutes.

1. The Good.

Some states, including California, Connecticut, and Hawaii, have had statutory protections in place for years that fill the void left by the lack of federal legislation, while other states, like Oregon, Illinois, and Indiana have enacted legislation more recently. ${ }^{157}$ Each state provides a measure of protection in the workplace for breastfeeding women who wish to express breast milk at work. ${ }^{158}$ These statutes are "good" because the laws: 1) mandate employer compliance; 2) set forth time, place, and manner guidelines for the accommodation of breastfeeding employees; and 3) have recognized a woman's right to breastfeed in public. ${ }^{159}$ The best of these state statutes, like Connecticut's and Hawaii's, go one step further-they specifically prohibit discrimination against women who choose to express breast milk or breastfeed in the workplace. ${ }^{160}$ Either of these statutes can serve as a model for any federal legislation that may be enacted.

California's statute provides that an employer shall "provide a reasonable amount of break time to accommodate an employee desiring to express breast milk for the employee's infant child." 161 Breastfeeding mothers are not entitled to additional break time beyond that which they would otherwise receive; instead, the break time to express breast milk should run concurrently with any other break time. ${ }^{162}$ If there is any additional break time required, then the

Montana, New Mexico, New York, North Dakota, Oklahoma, Oregon, Rhode Island, Tennessee, Texas, Vermont, Virginia, Washington, Wyoming. See id. Three of these states, Arkansas, Maine, and North Dakota, enacted workplace legislation in 2009. ARK. STAT. ANN. § 11-5-116 (Supp. 2009); ME. Rev. StAT. ANN. tit. 26, § 604 (Supp. 2009); N.D. CENT. CODE § 23-12-17 (Supp. 2009).

157. CAL. LAB. CODE §§ 1030-33 (West 2003); CONN. GEN. STAT. ANN. § 31-40w (West 2003); HaW. REV. STAT. ANN. § 378-2(7) (LexisNexis Supp. 2009); OR. REV. STAT. § 653.077 (2009); IND. CODE ANN. $\S$ 22-2-14-2 (LexisNexis Supp. 2009); 740 ILl. COMP. STAT. 137/5 (West Supp. 2010); 820 Ill. COMP. STAT. 260/10 (West 2004).

158. CAL. LAB. CODE §§ 1030-33 (West 2003); CONN. GeN. STAT. ANN. § 31-40w (West 2003); HaW. REV.STAT. ANN. §378-2(7) (LexisNexis Supp. 2009); OR. REV. STAT. § 653.077 (2009).

159. CAL. LAB. CODE §§ 1030-33 (West 2003); CONN. GEN. STAT. ANN. § 31-40w (West 2003); HaW. REV. STAT. ANN. § 378-2(7) (LexisNexis Supp. 2009); OR. REV. STAT. § 653.077 (2009).

160. CONN. GEN. STAT. ANN. § 31-40w(c) (West 2003) (“[a]n employer shall not discriminate against, discipline or take any adverse employment action against any employee because such employee has elected" to express breast milk or breastfeed"); HAW. REV. STAT. ANN. § 378-2(7) (LexisNexis Supp. 2009) (discriminatory practice for any employer to refuse to "hire or employ, or to bar or discharge from employment, or withhold pay, demote, or penalize a lactating employee because an employee breastfeeds or expresses milk at the workplace"). See also N.Y. LAB. LAW § 206c (McKinney 2009) ("No employer shall discriminate in any way against an employee who chooses to express breast milk in the work place."). In the District of Columbia, employers must provide break periods for expressing breast milk and must make reasonable efforts to provide a suitable environment in which to do so. D.C. CODE § 2-1402.82(d)(1)-(2) (Supp. 2009).

161. CAL. LAB. CODE $\S 1030$ (West 2003).

162. Id. 
remaining time is unpaid.163 California's statute applies to employers of all sizes. ${ }^{164}$

In Connecticut, "[n]o person may restrict or limit the right of a mother to breast-feed her child."165 In the workplace, an employer may not discriminate against, discipline, or take any adverse employment action against a woman because she chooses to express breast milk or breastfeed at work during meal or break periods. ${ }^{166}$ In fact, an employer, defined as a person engaged in business with one or more employees, shall make reasonable efforts to provide a room or location where the employee can express her breast milk privately. ${ }^{167}$

In Hawaii, a woman may breastfeed anywhere she otherwise has the right to be. ${ }^{168}$ If that right is violated, a woman may file a private cause of action and, if she prevails, she is entitled to reasonable attorneys' fees, court costs, and $\$ 100.169$ An employer in Hawaii may not "refuse to hire or employ, or to bar or discharge from employment, or withhold pay, demote or penalize a lactating employee because an employee breastfeeds or expresses milk at the workplace."170 Further, employers are required to permit employees to express breast milk or breastfeed during regular meal periods or breaks. ${ }^{171}$

Oregon moved from bad to good in its treatment of breastfeeding women in the workplace in 2008. In 2006, Oregon enacted legislation that permitted an employer to allow reasonable unpaid rest periods to accommodate breastfeeding mothers. ${ }^{172}$ The legislation provided for appropriate accommodations for time and location, but the entire statute was permissive, lacking any sort of incentive or enforcement mechanism. ${ }^{173}$ In 2008, Oregon made the accommodation of breastfeeding women in the workplace mandatory, but the statute still allows for an employer to demonstrate undue hardship in order to avoid compliance

163. Id. However, a bill was introduced in the California Assembly during the 2009-2010 regular session that would require paid twenty-minute breaks for lactating employees who wished to pump. Assem. B. 514, 2009 Leg., 2009-2010 Reg. Sess. (Cal. 2009). The amendment to § 1030 would require a break to be provided for every four hours of work and the breaks would not take the place of other legally mandated meal breaks. Id. As of April 12, 2010, the bill remained in committee. See Legislative Counsel, State of Cal., Bill Documents, http://www.leginfo.ca.gov/cgibin/postquery?bill_number=ab_514\&sess=CUR\&house=B\&author=de_leon (last visited Apr. 12, 2010).

164. Elizabeth L. Graves, Complying with California's New Lactation Accommodation Law, 25 L.A. LAW. 20, 20 (Feb. 2003). In her article, Graves uses the ADA as a point of comparison to demonstrate how employers would likely be required to comply with this new law.

165. CONN. GEN. STAT. ANN. § 53-34b (West 2007).

166. Id. §31-40w(a), (c) (West 2003).

167. Id. $\S 31-40 \mathrm{w}(\mathrm{b}),(\mathrm{d})$. The statute specifically states that the room cannot be a toilet stall. Id. $\S$ 31-40w(b). The statute also contains an undue hardship clause that protects employers where action would require "significant difficulty or expense when considered in relation to factors such as the size of the business, its financial resources and the nature and structure of its operation." Id. § 31$40 \mathrm{w}(\mathrm{d})$.

168. HAW. REV. STAT. ANN. § 489-21 (LexisNexis 2009).

169. Id. § 489-22.

170. HAW. REV. STAT. ANN. § 378-2 (LexisNexis 2009).

171. Id. §378-10. (LexisNexis 2004).

172. An Act of July 7, 2005, ch. 618, § 2, 2005 Or. Laws 2 (effective January 1, 2006).

173. See id. 
with the statute.174 The statute only applies to employers with more than twenty-five employees, and it only applies to women who are breastfeeding children under the age of eighteen months. ${ }^{175}$ While these are clearly less onerous than other drawbacks, they are still impediments to supporting a breastfeeding-friendly work environment.

Indiana has also recently moved from a permissive statute to one that requires an employer to accommodate a breastfeeding woman in the workplace. ${ }^{176}$ The statute provides that an employer shall "[t]o the extent reasonably possible," provide a private location where an employee can express breast milk and a refrigerator or other cold storage space for keeping milk that has been expressed. ${ }^{177}$ While the inclusion of a cold storage accommodation is an interesting statutory development, the statute has three distinct drawbacks: first, it only applies to persons or entities that employ twenty-five or more employees; ${ }^{178}$ second, it does not require an employer to accommodate an employee's need to express breast milk at certain times; and third, it does not prohibit discrimination against women who choose to express breast milk at work.

Illinois almost gets it right. While Illinois recognizes the importance of supporting breastfeeding, it merely requires break time for a nursing mother to express milk, while failing to require employers to provide a place for a mother to express that breast milk. 179

Montana provides comprehensive accommodation to breastfeeding mothers who return to work, even requiring written workplace policies supporting women who want to continue breastfeeding after returning to work. ${ }^{180}$ Montana has also rendered discriminatory employment practices against women who express breast milk in the workplace unlawful. ${ }^{181}$ The only problem in Montana is that all of this protection and support extends only to public employers; private employers are not required to support or encourage workplace accommodation for breastfeeding women. ${ }^{182}$

174. OR. REV. STAT. $§ 653.077(4)$ (2009). It is worth noting that the statute permits an employer to allow an employee to temporarily change job duties if the employee's regular job duties do not allow her to express milk. Id. § 653.077(6).

175. Id. §653.077(7), (8).

176. IND. CODE ANN. § 22-2-14-2 (LexisNexis Supp. 2009).

177. Id. § 22-2-14-2(b). Interestingly, the statute also protects employers from liability for any harm caused by or arising from the expression or storage of breast milk as long as there is no willful misconduct, gross negligence, or bad faith on the part of the employer. Id. § 22-2-14-2(c).

178. Id. § 22-2-14-1.

179. See 740 Ill. COMP. STAT. 137/5 (West Supp. 2010); 820 Ill. COMP. STAT. 260/10 (West 2004). § 260/10 also fails to define the term "unduly disrupt[s]." See also Miss. CODE. ANN. § 71-1-55 (Supp. 2009) (providing "No employer shall prohibit an employee from expressing breast milk during any meal period or other break period provided by the employer." There is no requirement that the employer provide a place to express breast milk.).

180. MONT. CODE ANN. § 39-2-215 (2009). See id. §§ 39-2-216 to 217.

181. Id. §39-2-215(2).

182. Id. § 39-2-215(1) (Public employers include state and county governments, municipalities, school districts, and the university system.). 


\section{The Bad. 183}

In 1993, Florida passed legislation exempting breastfeeding from criminal statutes. ${ }^{184}$ The state also recognized a mother's right to breastfeed her baby in any location, public or private, where the mother is otherwise authorized to be. ${ }^{185}$ Despite its early action, Florida has failed to keep pace with the current needs of women in the workplace and its legislation has remained stagnant. It does not even encourage or "allow" employers to accommodate breastfeeding women.

Several states, like Florida, have recognized the importance of breastfeeding in preambles and legislation, but these same states have failed to take any affirmative steps forward in terms of protecting a woman's rights in the workplace. ${ }^{186}$ Instead the states seem to pay lip service to the importance of the issue without acknowledging the scope of the problem or taking any decisive action.

Colorado moved to protect a woman's right to breastfeed in public in $2004 .{ }^{187}$ In doing so, it set forth a lengthy declaration of the benefits of breastfeeding. ${ }^{188}$ The Colorado legislature committed itself to "become involved in the national movement to recognize the medical importance of breastfeeding, within the scope of complete pediatric care, and to encourage removal of societal boundaries placed on breastfeeding in public."189 Colorado's recognition of the need without any action for the last five years has done little to advance the cause of breastfeeding women in the workplace. Kansas has similarly recognized the importance of breastfeeding and stated that "it is . . the public policy of Kansas that a mother's choice to breastfeed should be supported and encouraged to the greatest extent possible."190 However, Kansas has enacted no laws to protect a breastfeeding woman from discrimination in the workplace and it has enacted no laws requiring accommodation of breastfeeding women in the workplace.

Georgia protects a mother's right to breastfeed her child anywhere she is otherwise authorized to be.191 The state also recognizes that "[t]he breastfeeding of a baby is an important and basic act of nurture which should be encouraged in the interests of maternal and child health."192 Georgia has taken

183. In categorizing these statutory schemes, the author does not wish to minimize the large step forward several states have made in decriminalizing breastfeeding and in recognizing a woman's right to breastfeed in public, but in terms of developing a breastfeeding culture, particularly in the workplace, these states lag far behind.

184. Fla. StAT. ANN. §§ 800.02 - 800.04 (West 2007). See id. § 847.001(10) (West Supp. 2010) ("A mother's breastfeeding of her baby is not under any circumstance 'obscene.'”).

185. Id. §383.015 (West 2007).

186. See, e.g., COlO. Rev. StAT. ANN.§ 8-13.5-102 (2008); LA. ReV. StAT. ANN. § 51:2247.1 (2003);

NEV. REV. STAT. ANN. § 201.232 (LexisNexis 2006) (legislative declaration and statute issued in 1995).

187. Colo. Rev. StAT. ANN. § 25-6-302 (2008). See Act of Apr. 23, 2004, ch. 187, § 1, 2004 Colo. Sess. Laws 597 (effective Apr. 23, 2004).

188. COLO. Rev. StAT. ANN. § 8-13.5-102 (2008).

189. Act of Apr. 23, 2004, ch. 187, § 1, 2004 Colo. Sess. Laws 597 (effective Apr. 23, 2004).

190. KAN. STAT. ANN. §65-1,248 (Supp. 2008).

191. GA. CODE ANN. §31-1-9 (2009).

192. Id. 
the step of encouraging employers to accommodate breastfeeding mothers, but its statute is merely permissive. ${ }^{193}$

\section{The Ugly.}

While its treatment of breastfeeding women has recently improved, Arkansas provides a perfect example of what can happen without proper protection in the workplace. Prior to 2009, Arkansas did not provide any statutory protection for breastfeeding women in the workplace. ${ }^{194}$ Under Arkansas law, an individual is disqualified for unemployment benefits if he or she "voluntarily and without good cause connected with the work left his or her last work."195 The statute specifically exempts individuals who leave their last employment because of illness, injury, pregnancy, or disability after "making reasonable efforts to preserve his or her job rights."196

In 1993, Jolie Perdrix-Wang, a chemist, voluntarily left her employment when her employer would not accommodate her need to avoid exposure to certain chemicals while she continued to breastfeed her infant after returning to work. ${ }^{197}$ During her pregnancy, Perdrix-Wang had continued her work as a chemist under certain restrictions that limited the contact she could have with certain chemicals. ${ }^{198}$ When she returned to work, her baby's pediatrician recommended that she continue to avoid certain chemicals to protect the integrity of her breast milk. ${ }^{199}$ Perdrix-Wang sought a four month accommodation so that she could continue to breastfeed her child. 200

Perdrix-Wang's employer refused to accommodate her request because her decision to breastfeed was a personal one and not based on necessity. ${ }^{201}$ The Arkansas Court of Appeals, sitting en banc, found that "the mere fact that breastfeeding may be the 'best' of two available methods of feeding a child does not compel a finding of good cause to quit...."202 Instead the court held that Perdrix-Wang's decision was not supported by "medical advice or any evidence of the degree to which breast-feeding might benefit the baby or protect her from harm" and that she had failed to demonstrate good cause. ${ }^{203}$ The Arkansas statute protected voluntary separation based on disability, illness, and pregnancy, but the court refused to extend that protection to a breastfeeding woman who was faced with a choice that would impact her and her newborn infant's health. When her employer refused to continue the accommodation it

193. Id. § 34-1-6(b) (2008) (providing an employer may provide reasonable unpaid break time and an employer may make reasonable efforts to provide a room or other location). Strangely, the statute goes on to provide that "[a]n employer is not required to provide break time under this Code section if to do so would unduly disrupt the operations of the employer." Id.

194. ARK. CODE ANN. §§ 5-14-112, 20-27-2001 (Supp. 2009).

195. Id. § 11-10-513(a)(1).

196. Id. § 11-10-513(b)(2).

197. Perdrix-Wang v. Dir., Employment Sec. Dep't, 856 S.W.2d 636, 637-38 (Ark. 1993).

198. Id. at 637.

199. Id.

200. Id.

201. Id. at 638 .

202. Id. at 639.

203. Id. 
had already provided during her pregnancy, Perdrix-Wang was placed in "an untenable position of having to make a choice between Scylla of endangering the well-being of her child and Charybdis of being demoted."204

The appellate court went beyond simply failing to extend unemployment benefits to breastfeeding women who are unable to continue to work without reasonable accommodation. The court of appeals decision could have actually deterred a woman from continuing to breastfeed once she returns to work and offers no incentive for employers to support breastfeeding. It gave employers the right in all but the most limited circumstances to deny accommodation to breastfeeding women without penalty. Perhaps the most disheartening part of the court of appeals' decision was its failure to acknowledge the benefits of breastfeeding for any child, not just a child who may require breast milk for medical reasons. ${ }^{205}$

In Ohio, the Supreme Court decided to avoid the question in its entirety. ${ }^{206}$ LaNisa Allen filed suit against her employer alleging discrimination under Ohio's Fair Employment Practices Act and Pregnancy Discrimination Act. ${ }^{207}$ Allen took unauthorized breaks from her workstation during a two week period in order to pump breast milk; her supervisor terminated her for "failure to 'follow directions.'"208

The Ohio Supreme Court refused to address whether Allen, as a female lactating employee, could even state a cause of action for employment discrimination under Ohio law. In affirming the court of appeals, the Ohio Supreme Court held that there was no basis upon which a jury could conclude that the employer's articulated nondiscriminatory reason for her terminationinsubordination-was a pretext for discrimination based upon her pregnancy or conditions related to her pregnancy.209 Instead, Allen was simply and plainly terminated as an employee at will for taking an unauthorized, extra break.210

In her concurrence, Ohio Supreme Court Justice Maureen O'Connor took the majority to task for failing to address the larger question of whether

204. Id. at 640 (Rogers, J., dissenting) (Judge Rogers and Judge Robbins, who joined in the dissent, urged the legislature to consider the health benefits of breastfeeding.). As noted earlier, prior to, Arkansas's legislature had failed to take any steps in this direction.

205. Inherent in the court's decision is an acknowledgement that, in certain circumstances, breast milk is best. However, a healthy child is now not entitled to the same protection as a sickly child and the mother of a healthy child may not exercise her right to breastfeed her child because the child can tolerate infant formula.

206. Allen v. Totes/Isotoner Corp., 915 N.E.2d 622, 624 (Ohio 2009) (per curiam) (finding that the employer's stated reason for firing the plaintiff was legitimate and therefore supported a grant of summary judgment in its favor and refusing to consider whether or not she could state a cause of action for discrimination based on the fact she was lactating).

207. Id. at 623 (citing OHIO REV. CODE ANN. § 4112 (West Supp. 2010)).

208. Id. at 623,627 .

209. Id. at 624. Writing in dissent, Justice Pfeifer noted that it was unclear why the majority chose to approach the problem backward, relying on the legitimate nondiscriminatory reason and failing to answer the question of whether she even asserted a "cognizable cause of action." Id. at 632 (Pfeifer, J., dissenting).

210. Id. at 624 (per curiam). 
discrimination claims based on lactation alone are recognized by Ohio law. ${ }^{211}$ While the Ohio Supreme Court justices were in agreement that Allen could not prove a prima facie case, only Justice O'Connor's concurrence addressed the elephant in the room. Ultimately, she held that lactation falls within the scope of Ohio's Fair Employment Practices Act and that employment discrimination against lactating women is prohibited. ${ }^{212}$ Just like the Arkansas Court in PerdrixWang, the Ohio Supreme Court is sending mixed signals to women in the workplace. By focusing on the employer's reason for termination rather than whether she can state a claim for discrimination, the Court has effectively precluded lactating women from suing under the statute unless the employer expressly states that the termination was based on her status as a lactating woman.

Many states, like Idaho ${ }^{213}$ and Nebraska, ${ }^{214}$ merely permit a woman who is breastfeeding to request deferral of jury duty which does absolutely nothing to support and encourage a breastfeeding culture. Other states have simply done nothing.

\section{Proposed Solutions At THE FEDERAL LEVEL.}

In addressing this problem at a federal level, Congress must consider the underlying reasons why federal legislation is necessary to protect breastfeeding women in the workplace. Congress must also consider what is necessary to create effective legislation to protect a breastfeeding woman in the workplace. First, there is no federal law that protects a woman who chooses to breastfeed and work from suffering harassment or disparate treatment in the workplace. Second, there are significant health benefits that will inure to infants, mothers, employers, and society at large if employers are required to accommodate women who wish to breastfeed. Third, such legislation would prevent discrimination and would honor a woman's constitutional right to privacy. ${ }^{215}$ Finally, there is the need to address the disparate impact on the poorest and

211. Id. at 625-26. ( $\mathrm{O}^{\prime}$ Connor, J. concurring). Justices $\mathrm{O}^{\prime}$ Connor and Pfeifer were not alone in their opinion of the majority's approach. See id. at 625. (Moyer, C.J., concurring) (agreeing that summary judgment was properly granted, but joining Justice O'Connor's opinion based on her discussion of the merits).

212. Id. at 630. (O'Connor, J. concurring).

213. IDAHO CODE ANN. § 2-212 (Supp. 2009). It is worth noting that, in spite of its poor support of breastfeeding, Idaho has achieved some of the Healthy People 2010 objectives. See CTRS. FOR DiseAse CONTROL \& PREVENTION, BREASTFEEDING REPORT CARD, supra note 95.

214. NEB. REV. STAT. ANN. § 25-1601 (LexisNexis 2004).

215. The Fifth Circuit recognized that a woman's right to breastfeed deserved the same protection as other fundamental rights including marriage, procreation, contraception, abortion, and family relationships. Dike v. School Bd. of Orange County, 650 F.2d 783, 786 (5th Cir. Unit B July 1981), overruled by Shahar v. Bowers, 114 F.3d 1097, 1102 (11th Cir. 1997). However, the Eleventh Circuit later held that, to the extent the Fifth Circuit required application of strict scrutiny, it was overruled. Shahar, 114 F.3d at 1102 (analyzing the proper constitutional standard to be applied where an employee claimed a job offer was withdrawn based on her decision to enter into a samesex marriage). Even though Dike was overruled, there is still an argument that a woman's right to breastfeed should be considered in the same manner as procreation, contraception, abortion and family relationships. 
most vulnerable members of society, women and children, when it comes to the exercise of this right.

There is, however, another reason to enact such legislation which is discrete yet distinct. The enactment of federal legislation does more than create legal protections where none existed previously; it can recognize a sea change in society's values or crystallize an issue of importance. The legislative branch is often called upon to set a threshold in the workplace below which we, as a society, will not let others slip. ${ }^{216}$ Federal legislation has helped push through barriers of race, creed, color, gender, and disability in the workplace by placing a value on the contribution of certain members of our society and shifting our focus toward equal treatment while celebrating our differences. ${ }^{217}$

Breastfeeding is an oft-ignored gender issue that has not been adequately addressed. In our society, women's breasts carry a stigma of sexuality, sensuality, physicality, and desire. While there is nothing sexually explicit about breastfeeding, it carries the same stigma-fairly or not-because it often requires a woman to expose some part of her breast.218

In one instance, a woman who was breastfeeding her child discretely in her seat near the window, exposing no part of her skin, was removed from the flight before takeoff because she refused a flight attendant's request to cover her child with an airline blanket while she was nursing. ${ }^{219}$ The mother, Emily Gillette, who complied out of embarrassment, filed a complaint with the Vermont Human Rights Commission.220 An investigation by the Commission revealed that both Delta and Freedom Airlines permitted breastfeeding on their flights, but neither company had a written policy about breastfeeding on airplanes. ${ }^{221}$ Under Vermont law, a mother may breastfeed anywhere she otherwise has the

216. See Title VII of the Civil Rights Act of 1964, 42 U.S.C. § 2000e-2(a) (2006) (focusing on eradicating discrimination in the workplace); Americans with Disabilities Act, 42 U.S.C. § 12101(b)(4) (2006) (invoking the sweep of congressional authority including the power to enforce the Fourteenth Amendment and regulate commerce); Age Discrimination in Employment Act, 29 U.S.C. § 621(b) (2006) (recognizing the need to promote employment of older persons based on ability rather than age and to help employers and older workers find ways to address the impact of an aging population on employment).

217. United States v. Virginia, 518 U.S. 515, 533 (1996). The Supreme Court stated that inherent differences between men and women should be cause for celebration but not for artificial constraints on an individual's opportunity. Id. As a society, we should celebrate a woman's ability to breastfeed and reasonably accommodate that ability in the workplace, just as Congress has seen fit to do for pregnancy.

218. See Thomas Korosec, 1-Hour Arrest, When Does a Snapshot of a Mother Breast-feeding Her Child Become Kiddie Porn? Ask the Richardson Police, DALlas OBSERVER, Apr. 17, 2003, available at http://www.dallasobserver.com/2003-04-17/news/1-hour-arrest (mother and father arrested for photograph of mother breastfeeding toddler for sexual performance by a child and both children taken from parents by Child Protective Services in Texas).

219. Associated Press, Woman Kicked off Plane for Breast-feeding Baby, Nov. 16, 2006, available at http:/ / www.msnbc.msn.com/id/15720339.

220. Id.

221. Gillette v. Delta Air Lines, HRC Charge No. PA07-0007 (investigative report Mar. 27, 2008), at 22 (Vt. Hum. Rights Comm'n). The investigation revealed that the only person offended by the breastfeeding was the flight attendant who took it upon herself to have Gillette and her husband removed from the airplane. Id. at 4-5. 
right to be.222 The Vermont Human Rights Commission issued a Final Determination on March 27, 2008, finding that there were reasonable grounds to believe Mesa Air Group/Freedom Airlines illegally discriminated against Emily Gillette in public accommodations on the basis of breastfeeding.223

Sometimes federal legislation is necessary to send a message about what we as a society deem important, or about what rights should be recognized. When a woman chooses to breastfeed, she is making a personal, very unique choice about how she will use her body. In that sense, a woman who chooses to breastfeed is no different from a woman who chooses to become pregnant and give birth, and she should be afforded the same protection.

Any comprehensive legislation must address three crucial pillars of support. First, it must recognize that a woman has the right to breastfeed and should be given the opportunity to do so, even at work. In the case of Emily Gillette, this simple recognition allowed her to file a complaint with the Vermont Human Rights Commission. ${ }^{224}$

Second, protection under Title VII must be explicitly extended to breastfeeding women. Any such protection should clearly indicate it extends to women who are breastfeeding or who are expressing breast milk at work for consumption by their infant child. 225

Third, reasonable accommodation for breastfeeding women should be required of employers, regardless of size, unless the employer can demonstrate an undue hardship. 226

222. VT. StAT. ANN. tit. $9 \S 4502($ ) $)$ (Supp. 2009).

223. Gillette v. Delta Air Lines, HRC Charge No. PA07-0007 (final determination Mar. 27, 2008) (Vt. Hum. Rights Comm'n). On October 7, 2009, Gillette filed a complaint in federal court against Delta Airlines, Freedom Airlines and Mesa Air Group for violation of her civil rights. See Dave Gram, Woman Thrown Off Plane for Breast-feeding Sues, Associated PRESS FIN. Wire, Oct. 8, 2009.

224. Gillette v. Delta Air Lines, HRC Charge No. PA07-0007 (final determination Mar. 27, 2008) (Vt. Hum. Rights Comm'n); Bridget Barry Caswell, Commission: Airline Discriminated -Against Breastfeeding Mother, WCAX NEws, Mar. 27, 2008, available at http://www.wcax.com/global/ story.asp?s=8077241. It stands in stark contrast to Derungs wherein a federal court found that no law protected the rights of breastfed children and their mothers. See Derungs, 374 F.3d at 428. Fortunately, the ruling in Derungs prompted Ohio to adopt a statute protecting the right of a mother to breastfeed her child anywhere she has the right to be. See OHIO REv. CODE ANN. § 3781.55 (West 2006).

225. The current version of the Breastfeeding Promotion Act proposed by Representative Carolyn Maloney seeks to correct the deficiency in Title VII by explicitly protecting lactation from discrimination in the workplace. Breastfeeding Promotion Act, H.R. 2819, 111th Cong. (2009). The Act seeks "to clarify that breastfeeding and expressing breast milk in the workplace are protected conduct under the amendment made by the Pregnancy Discrimination Act of 1978 to [T]itle VII of the Civil Rights Act of 1964." Id. §101(b)(2).

226. The 2009 version of the Breastfeeding Promotion Act would amend section seven of the Fair Labor Standards Act to require that employers provide reasonable break time and a private place, other than a bathroom, for employees to express breast milk for one year after a child's birth. Breastfeeding Promotion Act, H.R. 2819, 111th Cong. § 501(a)(r)(1) (2009). Unfortunately, the same section also limits this requirement to employers who employ " 50 or more employees for each working day during each of 20 or more calendar workweeks in the current or preceding calendar year." Id. § 501(a)(r)(2). As of March 30, 2010, the substance of the 2009 Breastfeeding Promotion Act was adopted as part of Healthcare Reform. See NAT'L CONFERENCE OF STATE LEGIS., supra note 154. The new law amends the Fair Labor Standards Act, 29 U.S.C. $\$ 207$ (2006), to require employers to provide reasonable unpaid breaks for a woman to express breast milk for up to one year after the 
In enacting their own statutes, the states have adopted the language of reasonable accommodation. ${ }^{227}$ With respect to expressing breast milk or breastfeeding, reasonable accommodation should encompass a private place to pump breast milk or breastfeed, time within which to complete the pumping or breastfeeding during the workday, and a place to clean up after a woman has finished expressing her milk or breastfeeding her child. Such accommodations have been required by state statute. ${ }^{228}$ Policies which include a break during the workday so that a mother may express breast milk, a room set aside for mothers to express breast milk, and a place to clean equipment and store expressed milk, and sometimes even breast pumps do not appear to strain the employment environment and are reasonable accommodations for a woman's temporary needs. 229

\section{CONCLUSION}

The reality is that, with few exceptions, if a child is to receive breast milk, then that child's mother must provide the breast milk. It follows that the mother must be able to express her breast milk when she is separated from her child. Laws must evolve to afford all breastfeeding mothers reasonable accommodation to accomplish this task. Where state legislation has failed to safeguard breastfeeding mothers, the federal government should close up the rabbit hole that every Alice falls into when she makes the choice to breastfeed. Access to breast milk should not be dictated by class, the federal government should establish some continuity of opportunity for every woman who wants to continue breastfeeding when she returns to work.

Our government has committed itself time and again to the proposition that breastfeeding is best and should be supported. Research demonstrates that breastfeeding is not just a simple child care alternative, but that it is a preferred source of nutrition for infants, and one that has distinct short-term and longterm benefits. Statistics demonstrate that breastfeeding support may save money for families, employers, and federal programs over the long term but statistics demonstrate that the poorer, younger, less educated women in our society, who make up a large part of our workforce, are the least likely to receive the necessary support to initiate and continue breastfeeding. Only by safeguarding and advancing the rights of breastfeeding working mothers can we avoid forcing future generations of women into deciding between the same untenable choice of work or family, or worse, having no choice at all.

birth of her child. Id. While this is certainly a step forward at the federal level, it still remains to be seen how this law will be enforced. In addition, Congress still has not addressed discrimination against breastfeeding women in public, and in the workplace.

227. See, e.g., CAL. LAB. CODE $§ 1030$ (West 2003); CONN. GEN. STAT. ANN. § 31-40w (West 2003); OR. REV. STAT. § 653.077 (2009).

228. See, e.g., CAL. LAB. CODE $§ 1030$ (West 2003); CONN. GEN. STAT. ANN. § 31-40w (West 2003); HAW. ReV. STAT. ANN. § 378-2(7) (LexisNexis Supp. 2009); OR. REV. STAT. § 653.077 (2009).

229. See Kantor, supra note 20; Medela, supra note 64. 